\title{
Analysis of Relationships between Coaches' Organizational Justice and Leader-Member Exchange by Structural Equation Modeling
}

\author{
Yakup Akyel $^{1}$ \\ ${ }^{1}$ Ahi Evran Üniversitesi, Kırşehir, Turkey \\ Correspondence: Yakup Akyel, Ahi Evran Üniversitesi, Kırşehir, Turkey
}

Received: April 8, 2018

Accepted: June 5, 2018

Online Published: June 14, 2018

doi:10.5430/ijhe.v7n3p197

URL: https://doi.org/10.5430/ijhe.v7n3p197

\begin{abstract}
In this study, it was aimed to determine to what extent coaches' organizational justice levels were explained by a leader-member exchange. This study was conducted by using correlational survey model and its sub-purposes were to determine the coaches' organizational justice levels and to examine the differences in organizational justice levels according to their demographics. 230 coaches participated in the study. As a result of the study, it was determined that the organizational justice level of the coaches is generally moderate. It was found that coaches' organizational justice levels did not differ significantly among their genders, age, and marital status; on the other hand, those levels differed significantly among their seniority and ranks. As a result of the structural equation modeling, it was found that the coaches' leader-member exchange level was a positive and significant predictor $\left(\mathrm{R}^{2}=0.53\right)$ of their organizational justice level.
\end{abstract}

Keywords: organizational justice, leader-member exchange, coach, sports sciences

\section{Introduction}

Today, value of human resources has increased significantly and knowledge has become one of the most important power sources. Accordingly, organizations that invested in human beings have realized that they will earn more and therefore, they have wanted to guarantee their future. Today's successful organizations can be described as organizations with the largest number of well-equipped human resources, not with just a large number of employees (Naktiyok \& Yekeler, 2016). Organizational justice stands out as an important concept in these organizations that are formed to achieve. Organizational justice does not only mean providing the merit system in the organization; but also means that employees can demand good working conditions and wait for respect/sincerity at work (Taşkıran, 2011).

The basis for the work of organizational justice, which has become the focus of attention in different disciplines, is based on Adams' Equity Theory (1965). Adams' theory is based on the assumption that employees will compare their achievements because of their positions in the organization and their performances, with the achievements of the employees in similar organizations. Hereunder, it is emphasized that justice is important, particularly in the distribution or sharing of outputs obtained from production/service (Demirel \& Seçkin, 2011). The basis of Adams' Equity Theory is the desire of people to be treated fairly. According to the theory, equity is the belief that the individual is treated justly in comparison to other individuals, and inequity is the belief that the individual is not treated justly and fair in comparison to others (Griffin \& Moorhead, 1986).

Organizational justice includes the exercise and encouragement of fair and moral practices and procedures within the organization. In other words, in a fair organization, employees evaluate the behaviors of managers in a fair, ethical and rational way. Organizational justice is a fundamental requirement for effective organizations and positive satisfaction of employees (Akyel, 2017). On the other hand, the concept of organizational justice is defined as employees' perception and reflection of justice in the organization. Organizational justice generally focuses on what constructs the perception of whether employees are treated fairly in their organization and whether this affects other organizational outcomes (Alexander \& Ruderman, 1987).

In this context, it is possible to define organizational justice as perceptions of employees' self-evaluation of practices and standards provided by the organization (Campbell \& Finch, 2004). In addition, in the related literature, it is emphasized as a term that explains direct justice in the management sciences with the belief that employees are treated fairly and they have positive attitudes towards their work, their work-related gains, and their managers (Moorman, 1991). The definition of organizational justice in the light of this information can be expressed as follows: 
Organizational justice is the positive perception of the decisions and practices of the managers about the organization and the employees. In other words, it is the employees' perception on how the salaries, rewards, fines, and promotions are distributed in the organization, how these decisions are taken, and how these decisions are told to them (Akyel, 2017).

When the descriptions of the definition and scope of organizational justice are examined, the importance of communication and interaction in obtaining both justice and higher efficiency from the organizations can be better understood.

The evolution of organizations from solid and bureaucratic ones to modern ones with high social awareness has allowed communication and interactions to take place on a more horizontal level between superiors and subordinates. This brings the necessity of understanding and managing the formal / non-formal interactions of human resources, which is the largest capital of the organizations (Eryllmaz, Dirik \& Güloava, 2017). The interaction between the ruler and the ruled is evaluated together in the lead-member exchange. In the light of organizational changes, not only handling and managing employees but also working in collaboration by providing effective communication stands out in management philosophy. As a result, the approach of the leader-member exchange, which examines the interaction between the superior and the subordinate, remains its validity today (Besen \& Aktaş, 2016).

Leaders, high level of communication and interaction with their employees, will affect employees' perceptions of justice in the organization positively (Gürboyoğlu, 2009). There is a continuous interaction between employees and managers, and the quality of this interaction is influenced directly and indirectly by the perception of organizational justice (Kuzucu, 2013). Moreover, organizational justice is the perception of justice pertaining to the policies, procedures, and practices of the organization in which the employee is involved. For this reason, it affects the attitudes and behaviors of employees towards the organization. Alongside, when the source of justice is the managers, the interaction between the manager and the employees, and various organizational behaviors are formed towards the manager (Yürür \& Nart, 2016).

The concept of leader-member exchange is one of the developed theories in the framework of the social exchange theory (Blau, 1964), which attempts to explain the relationships among people in the exchange of the possessed resources (Göksel \& Ekmekcioglu, 2017; 724).

Several theories have been put forward in the organizational literature in order to understand the nature of the interaction between the superior and the subordinate. The foremost among these theories is the theory of leader-member exchange, which includes the processes related to the relationship between managers and employees (leaders and members) based on social interaction (Eryllmaz, 2017). Leader-member exchange is a theory that examines the process of the relationship development and its quality among individuals who are subject to social change. It generally tries to explain the intimacy and formality of the superior-subordinate relationship, and how it is shaped (Çekmecelioğlu \& Ülker, 2014). In general, the theory of leader-member exchange can be described as a dual process involving the social change that explains the roles and expectations that leader develops with each subordinate, based on mutual trust, respect, and loyalty, beyond the formal business relationship (Öztürk \& Şahin, 2017).

With the influence of economic, technological and socio-cultural developments in the world, and in the rapidly changing competition conditions, the human resources have great importance for the organizational success. At this point, in order to take advantage of the human resources potential in organizations, it is necessary to understand the organizational behaviors, the causes of these behaviors and the consequences they created (Bolat, 2011; 3). Particularly, in the service industry, the employees are in the positions such both producing services and serving them make these employees more important. On the other hand, the sport has gained an important place in social, economic and political dimensions of society. Therefore, justice perceptions of individuals engaged in organizational structures are seen as a situation that should be addressed by the institutions and administrators in the field of sports (Karademir \& Çoban, 2011).

Based on this information, this study aims to investigate the relationship between organizational justice and leader-member exchange of coaches who are the managers in the sports field. In order to have an in-depth analysis, structural equation model was used. In this sense, the relationship between organizational justice and leader-member exchange is examined from the perspective of coaches. In this respect, it is thought that this study will be beneficial with its theoretical framework, and application results to the related literature and the organizations that produce sports services. 


\section{Method}

This section provides information about the research design, the population and the sample, the data collection tools, and data analysis process.

\subsection{Research Design}

This study, which investigated the relationship between coach's organizational justice and leader-member exchange, was conducted by using correlational survey design. This design defines the relationship between variables; therefore, it is described as one of the descriptive research (Fraenkel \& Wallen, 2011). Correlational survey designs examine the relationship between two or more variables without any manipulation (Büyüköztürk et al., 2014).

\subsection{Population and Sample}

The population of the study consists of 230 coaches who actively work in sports club, have visas in 2017-2018 sport term. They are in the branches of wrestling, volleyball, taekwondo, table tennis which are the common branches in Turkey among 33 sports branches included in the Olympic Summer Sports Federation

\subsection{Data Collection Tools}

The data of this study were collected by organizational justice scale and leader-member exchange scale.

\section{Organizational Justice Scale}

In this study, Organizational Justice Scale, which was developed by Kim (2009) and was adapted to Turkish by Sayın and Şahin (2017), was used to determine the coaches' organizational justice levels. 17 items in total come under three dimensions; distributive justice, procedural justice and interactional justice. The items are rated on a Likert type 5-point scale and the high scores indicate that the individual's perception of organizational justice is high.

In the process of scale adaptation, items were translated to Turkish, and the opinions of field and language experts were taken. After editing the items according to the opinions, scale was administrated to 210 coaches. The assumptions about normality, outliers, and missing items were examined, and confirmatory factor analysis was conducted. After the analysis, it was found that all items in the scale had significant $t$ values, and their regression coefficients varied between 0,45 and 0,92. Moreover, it was confirmed that all items under three dimensions had significant model-data fit $(\mathrm{X} 2 / \mathrm{df}=3,93$; RMSEA=0,086; $\mathrm{CFI}=0,97$; $\mathrm{IFI}=0,97$; $\mathrm{NFI}=0,96)$. After confirmatory factor analysis, it was found that the item-total correlation coefficients of the scale items varied between 0,605 and 0,846 . The Cronbach alpha coefficient was calculated to determine the reliability of the answers given to the scale items and it was found that the reliability coefficients varied between 0,918 and 0,957 (Sayın \& Şahin, 2017: 212).

In this study, the organizational justice levels of 230 coaches were determined. The reliability coefficient of the answers given by the coaches to the items under the distributive justice dimension was found as 0,893 ; to the items under the procedural justice dimension was found as 0,904 ; and to the items under the interactional justice dimension was found as 0,904 . Accordingly, it can be said that the reliability of coaches' answers was high.

\section{Leader-Member Exchange Scale}

The Leader-Member Exchange Scale, which was developed by Liden and Maslyn (1998) and adapted to Turkish by many researchers, was used to determine the leader-member exchange levels of the coaches. There are 12 items in total rated on a Likert type 5-point scale. The items are grouped into four dimensions with three items in each: affect, loyalty, contribution, and professional respect.

Baş et al. (2010) found that the Cronbach alpha coefficients for the internal consistency were as follows: it was .920 for the affect dimension; .864 for the loyalty dimension; .700 for the contribution dimension; and .903 for the professional respect dimension.

Leader-Member Exchange Scale was used in other studies as well. For instance Altay (2011) used the multifactorial design and found that the goodness of fit values were good $(\mathrm{X} 2 / \mathrm{df}=2.41$, GFI=.94, AGFI=.91, TLI=.93, IFI=.95, $\mathrm{CFI}=.95$, RMSEA=.07). It was also found that the factor loading of the items varied between .57 and .86 , and the Cronbach alpha coefficient was high $(\alpha=0.84)$.

In this study, the leader-member exchange scale was applied to the 230 coaches to identify their leader-member exchanges. Calculated Cronbach alpha coefficient of reliability for items under the affect dimension was found as 0.909 ; for items under the loyalty dimension was found as 0,760 ; for items under the contribution dimension was found as 0,801 ; and for items under the professional respect dimension was found as 0,908 . The reliability of the answers given by the coaches to the all items in the leader-member exchange scale was also calculated as 0.930 . In this context, it was found that the answers that coaches gave to the leader-member exchange scale were reliable. 


\subsection{Data Analysis}

Descriptive statistics were firstly calculated based on the answers obtained from the coaches. Then independent samples t-test and one-way variance analysis were calculated to determine whether organizational justice and leader-member exchange differed significantly according to their demographics. A structural equation model was constructed to determine the relationship between coaches' organizational justice and leader-member exchange levels.

Structural equation model is a set of statistical techniques, which explains the relationship between one or more continuous or categorical independent variable and one or more continuous or categorical dependent variable (Tabachnick \& Fidell, 2007). Structural equation model is a statistical technique, which was used to test models, include the causal and correlational relationship between observed and covert variables. It is a multivariable method, which consists multiple analysis such as variance and covariance analysis, factor analysis and multiple regression (Çerezci, 2010).

Before model calculation was carried out, the assumptions of the structural equation model were examined. First, it was determined that the sample size was sufficient $(n=230)$. It has been determined that there were no missing data in the dataset. Z statistics and box graphs were used to determine the univariate outliers, and two outlier data were extracted from the dataset. The Mahalonobis distance measure was calculated for the multivariate outlier test, and one outlier was extracted from the dataset. When the skewness-kurtosis coefficients for the normality assumption of the variables were examined, it was determined that the coefficients were between -1 and +1 , and the histogram graphs were examined, therefore it was found that the data was normally distributed.

For multivariable normality, the scattering diagram matrix was examined and it was determined that the variables met the assumption of the multivariate normality. The multivariable normality hypothesis also provides information on multicollinearity. In order to examine the multicollinearity and singularity, correlation coefficients between variables were calculated. It was found that significant correlation coefficients varied between 0,271 and 0,616, therefore it was determined that there was no multicollinearity. The Box's $M$ test, which was calculated for the assumption of homoscedasticity, found that homogeneity of variances was achieved. Following the examination of the assumptions, analyzes were calculated with 227 data.

\section{Findings}

\subsection{Findings regarding Coaches' Organizational Justice Levels}

Descriptive statistics were calculated to determine the level of organizational justice of the coaches and the results are shown in Table 1.

Table 1. Descriptive statistics of coaches' scores they took from the Organizational Justice Scale

\begin{tabular}{ccccccc}
\hline Scale & Dimensions & Minimum & Maximum & $\overline{\mathrm{X}}$ & SD & Item-based average \\
\hline Distributive & 4,00 & 20,00 & 12,16 & 4,38 & 3,0 \\
& Procedural & 7,00 & 35,00 & 22,19 & 6,74 & 3,2 \\
Interactional & 6,00 & 30,00 & 20,24 & 5,56 & 3,4 \\
Organizational Justice & 17,00 & 85,00 & 54,59 & 14,88 & 3,2
\end{tabular}

When the table is examined, it can be seen that the average scores of the coaches regarding overall and dimensions of organizational justice scale were generally moderate. In other words, distributive, procedural and interactional justice perceptions of coaches participating in the survey were calculated at similar levels. Furthermore, it was determined that the interactional justice dimension with the ratio of 3,4 had the highest average.

It was investigated whether organizational justice levels showed a significant change according to their demographics and the results are shown in Table 2 to Table 6. 
Table 2. Independent Samples T-Test results on the coaches' organizational justice scores according to their gender

\begin{tabular}{lccccccc}
\hline Scale Dimensions & Gender & $\mathrm{N}$ & $\overline{\mathrm{X}}$ & $\mathrm{SD}$ & $\mathrm{df}$ & $\mathrm{t}$ & $\mathrm{p}$ \\
\hline Distributive & Male & 181 & 12,36 & 4,49 & 225 & 1,411 & 0,160 \\
& Female & 46 & 11,35 & 3,81 & & & \\
Procedural & Male & 181 & 22,53 & 6,76 & 225 & 1,516 & 0,131 \\
& Female & 46 & 20,85 & 6,56 & & & \\
Interactional & Male & 181 & 20,48 & 5,74 & 225 & 1,253 & 0,212 \\
& Female & 46 & 19,33 & 4,77 & & & \\
Organizational Justice & Male & 181 & 55,37 & 15,20 & 225 & 1,574 & 0,118 \\
& Female & 46 & 51,52 & 13,28 & & & \\
\hline
\end{tabular}

As shown in Table 2, it was determined that the values in overall and in dimensions of organizational justice scale were higher in men, but this result was not statistically significant.

Table 3. One-way variance analysis (ANOVA) results on the coaches' organizational justice scores according to their ages

\begin{tabular}{llrrrrr}
\hline Scale Dimensions & Age & $\mathrm{N}$ & $\overline{\mathrm{X}}$ & $\mathrm{SD}$ & $\mathrm{F}$ & $\mathrm{p}$ \\
\hline Distributive & $21-30$ & 76 & 12,80 & 4,69 & & \\
& $31-40$ & 80 & 12,40 & 3,74 & 2,699 & 0,069 \\
& 41 and over & 71 & 11,20 & 4,58 & & \\
Procedural & $21-30$ & 76 & 22,84 & 6,54 & & \\
& $31-40$ & 80 & 22,79 & 6,63 & 2,165 & 0,117 \\
Interactional & 41 and over & 71 & 20,82 & 6,96 & & \\
& $21-30$ & 76 & 20,28 & 5,87 & & \\
Organizational Justice & $21-30$ & 80 & 20,60 & 5,40 & 0,386 & 0,680 \\
& $31-40$ & 71 & 19,80 & 5,45 & & \\
& 41 and over & 76 & 55,92 & 14,85 & & \\
& $31-40$ & 80 & 55,79 & 14,43 & 1,809 & 0,166
\end{tabular}

As shown in the table, the distributive justice $(\mathrm{F}(2,224)=2,699 ; \mathrm{p}>0,05)$, procedural justice $(\mathrm{F}(2,224)=2,165 ; \mathrm{p}>0,05)$, interactional justice $(\mathrm{F}(2,224)=0,386 ; \mathrm{p}>0,05)$ and overall organizational justice $(\mathrm{F}(2,224)=1,809 ; \mathrm{p}>0,05)$ were not significantly different according to the age groups.

Table 4. Independent Samples T-Test results on the coaches' organizational justice scores according to their marital status

\begin{tabular}{llrccccc}
\hline Scale Dimensions & Marital Status & $\mathrm{N}$ & $\overline{\mathrm{X}}$ & $\mathrm{SD}$ & $\mathrm{df}$ & $\mathrm{t}$ & $\mathrm{p}$ \\
\hline Distributive & Married & 140 & 11,89 & 4,26 & 225 & 1,193 & 0,234 \\
& Single & 87 & 12,60 & 4,54 & & & \\
Procedural & Married & 140 & 21,51 & 6,71 & 225 & 1,947 & 0,053 \\
& Single & 87 & 23,29 & 6,68 & & & \\
Interactional & Married & 140 & 19,96 & 5,39 & 225 & 0,980 & 0,328 \\
& Single & 87 & 20,70 & 5,83 & & & \\
Organizational Justice & Married & 140 & 53,35 & 14,72 & 225 & 1,599 & 0,111 \\
& Single & 87 & 56,59 & 15,01 & & & \\
\hline
\end{tabular}


In the table 4 , it can be seen that the levels of distributive justice $(t(225)=1,193 ; p>0.05)$, procedural justice $(\mathrm{t}(225)=1,947 ; \mathrm{p}>0,05)$, interactional justice $(\mathrm{t}(225)=0,980, \mathrm{p}>0,05)$, and organizational justice $(\mathrm{t}(225)=1,599$, $\mathrm{p}>0,05)$ did not show any significant difference based on coaches' marital status. Although there is no statistically significant difference, it is seen that the average organizational justice scores of single coaches are higher.

Table 5. One-way variance analysis (ANOVA) results on the coaches' organizational justice scores according to their seniority

\begin{tabular}{llrrrrr}
\hline Scale Dimensions & Seniority & $\mathrm{N}$ & $\overline{\mathrm{X}}$ & $\mathrm{SD}$ & $\mathrm{F}$ & $\mathrm{p}$ \\
\hline Distributive & 0-5 years & 71 & 12,72 & 4,13 & & \\
& 6-10 years & 52 & 13,00 & 4,02 & 2,290 & 0,079 \\
& 11-15 years & 53 & 11,53 & 4,89 & & \\
Procedural & 16 years and over & 51 & 11,18 & 4,32 & & \\
& 0-5 years & 71 & 23,52 & 6,28 & & \\
& 6-10 years & 52 & 23,12 & 5,73 & 2,862 & 0,038 \\
11-15 years & 53 & 20,45 & 7,75 & & \\
Interactional & 16 years and over & 51 & 21,20 & 6,83 & & \\
0-5 years & 71 & 21,25 & 5,20 & & \\
& 6-10 years & 52 & 20,52 & 5,64 & 1,761 & 0,156 \\
11-15 years & 53 & 19,06 & 6,18 & & \\
& 16 years and over & 51 & 19,78 & 5,15 & & \\
0-5 years & 71 & 57,49 & 13,79 & & \\
& 6-10 years & 52 & 56,63 & 12,78 & 2,752 & 0,044 \\
& 11-15 years & 53 & 51,04 & 17,34 & & \\
& 16 years and over & 51 & 52,16 & 14,81 & &
\end{tabular}

As can be seen in table, it was determined that the distributive justice $(F(3,223)=2,290 ; p>0,05)$ and interactional justice $(F(3,223)=1,761 ; p>0,05)$ did not show any significant difference according to coaches' seniority. However, it was determined that the scores of procedural justice $(\mathrm{F}(3,223)=2,862 ; \mathrm{p}<0,05)$ and organizational justice $(\mathrm{F}(3,223)=2,752 ; \mathrm{p}<0,05)$ were significantly different according to their seniority. The multiple comparison LSD tests were calculated to determine the difference. As a result of the calculation, it was found that the procedural justice levels of coaches with 11-15 years of seniority were significantly lower $(20,45 \pm 7,75)$ than those with $0-5$ years seniority $(23,52 \pm 6,28)$ and with $6-10$ years seniority $(23,12 \pm 5,73)$. As seen in the results of coaches' organizational justice according to their seniority, the organizational justice levels of the coaches with $0-5$ years seniority were found to be significantly higher $(57,49 \pm 13,79)$ than those with $11-15$ years seniority $(51,04 \pm 17,34)$ and those with 15 years seniority and over $(52,16 \pm 14,81)$. In other words, as the duration of coaching increased, the perceptions scores of the overall organizational justice scale and procedural justice dimension decreased significantly. 
Table 6. One-way variance analysis (ANOVA) results on the coaches' organizational justice scores according to their ranks

\begin{tabular}{lcccccc}
\hline Scale Dimensions & Rank & N & $\bar{X}$ & SD & F & p \\
\hline Distributive & I. Rank & 58 & 12,93 & 3,89 & & \\
& II. Rank & 99 & 12,36 & 4,27 & 4,224 & 0,006 \\
& III. Rank & 45 & 10,20 & 4,59 & & \\
Procedural & IV. Rank & 25 & 13,08 & 4,63 & & \\
& I. Rank & 58 & 23,74 & 6,11 & & \\
& II. Rank & 99 & 22,75 & 6,31 & 5,292 & 0,002 \\
Interactional & III. Rank & 45 & 18,82 & 7,29 & & \\
& IV. Rank & 25 & 22,44 & 7,10 & & \\
& I. Rank & 58 & 21,60 & 4,74 & & \\
& II. Rank & 99 & 20,49 & 5,75 & 4,954 & \\
Organizational Justice & III. Rank & 45 & 17,60 & 5,54 & & \\
& IV. Rank & 25 & 20,84 & 5,36 & & \\
& I. Rank & 58 & 58,28 & 13,29 & & \\
& II. Rank & 99 & 55,61 & 14,27 & 6,152 & \\
& III. Rank & 45 & 46,62 & 15,46 & & \\
& IV. Rank & 25 & 56,36 & 15,38 & & \\
\hline
\end{tabular}

According to information in the table, the distributive justice $(\mathrm{F}(3,223)=4,224, \mathrm{p}<0,05)$, procedural justice $(F(3,223)=5,292, p<0,05)$, interactional justice $(F(3,223)=4,954 ; p<0,05)$, and organizational justice $(F(3,223)=6,152$; $\mathrm{p}<0,05)$ scores showed a significant difference. Multiple comparison LSD tests were calculated, consequently, it was determined that the coaches of the third rank had significantly lower justice perceptions than the coaches of the other levels in all dimensions of the scale.

\subsection{Findings regarding the Relationship between Coaches' Organizational Justice Levels and Leader-Member Exchanges}

Coaches' organizational justice levels are explained by the dimensions of distributive justice, procedural justice, and interactional justice. Coaches' leader-member exchanges also have affect, loyalty, contribution, and professional respect dimensions. The relationship between coaches' organizational justice levels and leader-member exchange levels was examined by structural equation modeling.

The path diagram created by the analysis of the structural equation modeling established to determine the relationship between coaches' organizational justice levels and leader-member exchange levels is shown in the Figure 1. 


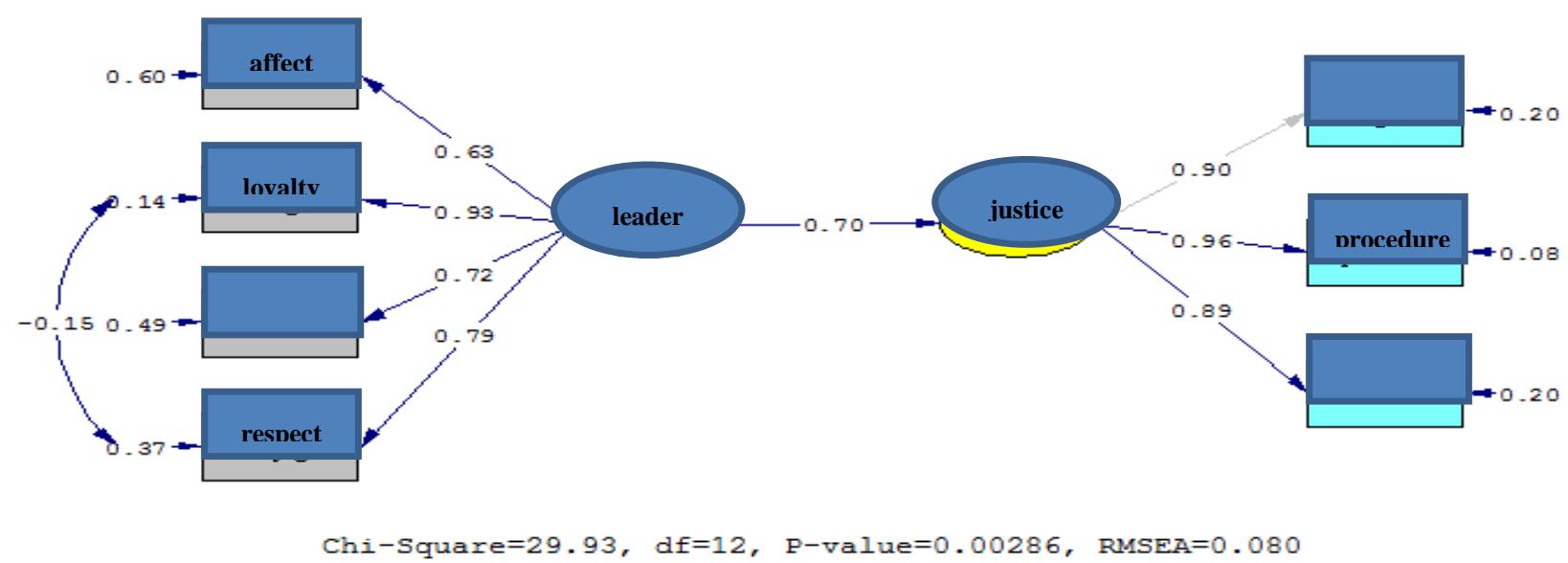

Figure 1. The Calculated Model for Relationship between Coaches' Organizational Justice Levels and Leader-Member Exchange Levels (Standardized Coefficients)

It was determined that the $t$ values of all the variables in the figure were significant, in other words, they were significant explanations of the related variable in the model. In the model calculation phase, the lambda, standardized regression coefficient and $t$ values were calculated for the dimensions (observed variables), and the results are shown in the Table.

Table 7. Lambda, Regression and t Coefficients Calculated for Dimensions (Observed Variables) in Model Created to Describe Coaches' Organizational Justice Levels

\begin{tabular}{lcccr}
\hline Scale & Dimensions & $\begin{array}{c}\text { Standardized Factor Loads } \\
(\lambda)\end{array}$ & $\begin{array}{c}\text { Regression values } \\
\left(\mathrm{R}^{2}\right)\end{array}$ & t value \\
\hline \multirow{3}{*}{ Organizational Justice } & Distributive & 0,90 & 0,80 & --- \\
& Procedural & 0,96 & 0,92 & 24,01 \\
& Interactional & 0,89 & 0,80 & 20,64 \\
& Affect & 0,63 & 0,45 & 11,00 \\
Leader-member exchange & Loyalty & 0,93 & 0,76 & 15,77 \\
& Contribution & 0,72 & 0,53 & 12,13 \\
& Professional Respect & 0,79 & 0,51 & 11,84 \\
\hline
\end{tabular}

The table illustrates that the organizational justice scale had a high level of correlation with the distributive $(\lambda=0,90)$, procedural $(\lambda=0,96)$ and interactional $(\lambda=0,89)$ dimensions. It was found that the highest relationship with organizational justice was procedural justice dimension. It can be seen in the table that there was a moderate and high level of relationship between coaches' leader-member exchanges and its dimensions. The highest relationship with leader-member exchanges was calculated with the loyalty dimension $(\lambda=0,93)$.

The standardized regression coefficients (R2) indicated how much of the explained variance in the observed variable was due to the covert variable. Similarly, coaches' organizational justice levels seemed to be most explained by the procedural justice dimension $(R 2=0.92 ; p<0.05)$. Thereafter, distributive $(R 2=0.90, p<0.05)$ and interaction $(R 2=0.89$, $\mathrm{p}<0.05)$ justice were significant predictors of coaches' organizational justice levels. It was found that coaches' leader-member exchanges were most explained by the loyalty dimension $(\mathrm{R} 2=0.76, \mathrm{p}<0.05)$. It was followed by professional respect $(R 2=0,79 ; p<0,05)$, contribution $(R 2=0,72 ; p<0,05)$, and affect $(R 2=0,63 ; p<0,05)$ dimensions.

The structural equation has been formed as seen in the model in Figure 1, and it has been determined that coaches' organizational justice levels were explained significantly by their leader-member exchanges. 
Table 8. Calculated Beta, Error Variance and Regression Coefficients Related to the Covert Variables in the Model Constructed to Explain Coaches' Organizational Justice Levels

\begin{tabular}{lcccc}
\hline Variable & $\beta$ & Variable & Error variance & $\mathrm{R}^{2}$ \\
\hline Organizational Justice & 0,73 & Leader-member exchange & 0,47 & 0,53 \\
\hline
\end{tabular}

The table shows that the coaches' leader-member exchanges explained 53\% of the change in levels of organizational justice. It was determined there was a positive and high level of relationship between coaches' leader-member exchanges and organizational justice levels $(\beta=0.73)$. In other words, it was found that as the level of coaches' leader-member exchanges increased, organizational justice levels increased. After the model calculation phase, the model-data fit indexes were calculated. The results of fit indexes are given in the Table.

Table 9. Model-Data Fit Indexes for Models Constructed to Explain Coaches' Organizational Justice Levels

\begin{tabular}{lccc}
\hline Fit Criteria & Perfect Fit & Acceptable Fit & Model values \\
\hline $\mathrm{X}^{2} / \mathrm{df}$ & $0 \leq \mathrm{X}^{2} / \mathrm{df} \leq 4$ & $0 \leq \mathrm{X}^{2} / \mathrm{df} \leq 5$ & 2,49 \\
RMSEA & $0 \leq \mathrm{RMSEA} \leq .05$ & $.05<\mathrm{RMSEA} \leq .08$ & 0,080 \\
NFI & $.95 \leq \mathrm{NFI} \leq 1.00$ & $.90 \leq \mathrm{NFI}<.95$ & 0,98 \\
NNFI & $.97 \leq \mathrm{NNFI} \leq 1.00$ & $.95 \leq \mathrm{NNFI}<.97$ & 0,98 \\
$\mathrm{CFI}$ & $.95 \leq \mathrm{CFI} \leq 1.00$ & $.90 \leq \mathrm{CFI}<.95$ & 0,99 \\
GFI & $.95 \leq \mathrm{GFI} \leq 1.00$ & $.90 \leq \mathrm{GFI}<.95$ & 0,96
\end{tabular}

It can be seen in the table that X2 / df, NFI, NNFI, CFI and GFI values fitted perfectly with the model; the RMSEA value also indicated that model fitted with the acceptable limit. In this respect, it was determined that the model established to explain the levels of coaches' organizational justice fitted with the data obtained from the coaches, in other words, it was determined that the coaches' organizational justice was explained by the leader-member exchanges significantly.

\section{Conclusion and Discussion}

In that study, it was aimed to investigate the relationships between coach's organizational justice levels and leader-member exchanges with structural equation modeling. Accordingly, first, the coaches' levels of organizational justice, and whether those levels showed a significant difference according to their demographics characteristics were investigated. The model was tested by constructing a structural equality model to explain the coaches' organizational justice levels.

It was determined that the coaches' distributive justice, procedural justice, and organizational justice perception were generally moderate, and their interactional justice was at a high level of 3.4 (Table 1).

Coaches, who are one of the most important inputs of sports clubs, give their labor to their organizations by using their knowledge, skills, and attitudes. The level of organizational behavior such as organizational justice increases the organizational productivity by affecting the coaches (Tolukan et al., 2016). In his study, Mikula (2002) suggested that the low perception of organizational justice would lead to an increase in the levels of unwanted organizational behaviors such as loss of motivation, poor performance, job dissatisfaction, and tendency to leave work. In this study, it was seen that, according to the coaches, the level of sharing the club resources among the individuals, perception of sharing them as fair, and the methods of making a decision of distribution were moderately fairly perceived by the stakeholders. From this point of view, it can be stated that the methods and programs of the sports clubs should be redesigned to increase the coaches' distributive justice and procedural justice perceptions.

In this study, it was determined that the average of male coaches' scores were higher in all dimensions of organizational justice perception, but these ratios were not statistically significant (Table 2).

In the related literature, the results of research on justice perceptions and gender are not always consistent (Süral \& Özer, 2007). For example, Çakar (2015) found that female faculty members had more anticipation of justice perception than male faculty members did, and this was explained as one of the factors affecting the working patterns of the employees in the institution. Nevertheless, Başar (2011), Çırak and Atanur (2013) found that there was no difference between the justice perceptions of men and women in their study. The fact that the level of organizational justice of the people participating in the coaching visa courses in 2017 did not show a significant difference 
according to their genders was an indication of the similar perception of the concept of justice by both genders, and it can be interpreted as a positive result.

In addition, it was determined that the levels of distributive justice, procedural justice, interactional justice and organizational justice did not change significantly according to their age and marital status (Table 3 and Table 4).

When the levels of organizational justice perception according to coaches' seniority were examined, it was seen that those who are in 0-5 years and 6-10 years had a higher perception of justice in all dimensions than those who are in 11-15 years and 15 years and over seniority categories, and this ratio produced a significant difference in organizational justice scale in terms of overall and procedural justice dimension (Table 5). In other words, it was observed that the sense of organizational justice increased as the coaches decreased in seniority. This finding is consistent with the study of Akyel et al. (2014) on the staff of the sport general director, who found that the perceptions of justice for organizational justice diminish as the duration of service increases. It was also consistent with the study of Toğa (2016) who found that the average of participants with 0-4 years of seniority had a higher average than the other age groups. The fact that beginners in coaching are more idealistic and want to do everything on their merit may be a reason of it. The fact that coaches with high seniority are in a struggle to keep pace with change and tend to move on from prior knowledge about rules and distributions can be a cause for low organizational justice. Just because organizational structures also change as time changes.

The levels of coaches' distributive justice, procedural justice, interactional justice and organizational justice showed significant changes based on their ranks. The organizational justice levels of the third level coaches were found to be significantly lower than those of the other levels (Table 6).

A model of structural equality to explain organizational justice was established in order to determine the relationship between coaches' organizational justice and leader-member exchange. In the model, the relationship between the scale (covert variables) and the dimensions (observed variables) was examined first. It was determined that the levels of coaches' organizational justice perception were significantly and highly explained by procedural, distributive and interactional justice perception levels. Likewise, leader-member exchanges were found to be significantly explained by loyalty, professional respect, contribution, and affect dimensions, respectively (Figure 1).

The theory of justice perception indicates that the struggle of the leader to provide justice has increased the leader-member exchange. When it is thought that the struggle of the leader to provide justice in the environment is within the factor of creating a positive working environment of the manager trust factors, it can be stated that this theory is related to the findings of our study (Köy, 2011). Kim and Andrew (2015) found that procedural and interaction justice dimensions were highly correlated with leader-member exchanges and that the strongest relationship was procedural justice supports the research results. Moreover, the conclusion in the same study, which distributive justice were not related to the leader-member exchange, differs from the results of this study (Kim and Andrew, 2015). The findings of the study are consistent with the findings of Gürboyoğlu (2009). According to this study, there was a meaningful and positive relationship between leader-member exchange and organizational justice perception $(r=.873)$. As the quality of the leader-member exchange increased, perceptions of organizational justice also developed positively. The leader should clearly define the principles to be based on the determination of wages, rewards, bonuses and other benefits to be provided for the provision of justice; create an atmosphere of confidence that it will not misuse its powers; behave neutral to all employees (Gürboyoğlu, 2009). It was observed that the leader-member exchange is closely related to both organizational citizenship behavior and organizational justice, and correspondingly, it is suggested that the leader-member exchange can have an intermediary role. While employees with high organizational justice perceptions are in the internal group according to relations with their superiors, those with low organizational justice perceptions are in the external group (Kuzucu, 2013).

As a result of the structural equation calculated in the model, it was determined that the coaches' leader-member exchange explained $53 \%$ of the change in organizational justice levels. X2/df, NFI, NNFI, CFI, and GFI from model-data fit indexes also showed excellent fit; the RMSEA value also indicated that it fitted with the acceptable limit. In another expression, it was found that the coaches' level of organizational justice was significantly explained by the leader-member exchanges. According to the social change model developed by Masterson et al. (2000), it was revealed that interactional justice from the components of organizational justice has the strongest influence on the managerial dimension of organizational citizenship behavior. In addition to this finding, it was noted that the leader-member exchange factor has an intermediary role on the relationship between interactional justice and organizational citizenship behavior. 
According to the findings obtained in this study, it was also seen that it is important to increase the leader-member exchange in order to increase the organizational justice levels of the coaches. In this context, it can be said that training of communication and interaction with coaches is important for the future and success of sports.

\section{References}

Akyel, Y. (2017). Yönetim bağlammında adalet ve güven. Pegem A Yayıncılık: Ankara.

Akyel, Y., Şahin, M.Y., \& Günay, M. (2014). Perceptions of the staff of the general directorate of sports about organizational justice. Kastamonu Üniversitesi İktisadi ve İdari Bilimler Fakültesi Dergisi, 5(3), 55-65.

Alexander, S., \& Ruderman, M. (1987). The role of procedural and distributive justice in organizational behavior. Social Justice Research, (1), 177-198.

Başar, U. (2011). Örgütsel adalet algısl, örgütsel özdeşleşme ve iş tatmini arasındaki ilişsilere yönelik görgül bir araştırma. Yüksek Lisans Tezi, Kara Harp Okulu Savunma Bilimleri Enstitüsü. Ankara.

Baş, T., Keskin, N., \& Mert, İ.S. (2010). Lider üye etkileşimi (LÜE) modeli ve ölçme aracının Türkçe'de geçerlik ve güvenirlik analizi. Ege Akademik Bakış/Ege Academic Review, 10(3): 1013-1039.

Besen, E, \& Aktaş, H. (2016). Birey-örgüt uyumu ve yöneticiye duyulan güven ile lider-üye etkileşimi bağlamında bursa'da otomotiv sektörü çalışanları üzerinde bir araştırma. YÖNETIM: İstanbul Üniversitesi Iş̧letme İktisadi Enstitüsü Dergisi, 27(81): 1-19.

Bolat, İ. (2011). Öz yeterlilik ve lider üye etkileşimi ilişkisi. Detay Yayıncılık: Ankara.

Büyüköztürk, Ş., Kılıç-Çakmak, E., Akgün, Ö. E., Karadeniz, Ş., \& Demirel, F. (2014). Bilimsel araştırma yöntemleri. Pegem Akademi: Ankara.

Campbell, L., \& Finch, E. (2004). Customer satisfaction and organizational justice. Facilities 22(7/8), 178-189.

Çakar, N.D. (2015). Toplumsal cinsiyet temelinde örgütsel adalet algısı: etik iklimin rolü. KADEM Kadın Araştırmaları Dergisi, 1(2): 79-94.

Çakmak, K. (2005). Performans değerlendirme sistemlerinde örgütsel adalet algısı ve bir örnek olay çalışması. Yüksek Lisans Tezi, İstanbul Üniversitesi Sosyal Bilimler Enstitüsü, İstanbul.

Çekmecelioğlu, H.G., \& Ülker, F. (2014). Lider - üye etkileşimi ve çalışan tutumları üzerindeki etkisi: eğitim sektöründe bir araştırma. Kocaeli Üniversitesi Sosyal Bilimler Dergisi, 28, 35-58.

Çerezci, T.E. (2010). Yapısal eşitlik modelleri ve kullanılan uyum iyiliği indekslerinin karşılaştırılması, Doktora Tezi, Gazi Üniversitesi Fen Bilimleri Enstitüsü, Ankara

Çırak, S. (2013). Atanur Başkan G. İlköğretim okulu öğretmenlerinin örgütsel adalet algısı (Ankara / Yenimahalle). $K$. Ü. Kastamonu Ĕ̈itim Dergisi, 23(3): 1091-1106.

Demirel, Y., \& Seçkin, Z. (2011). Örgütsel adaletin bilgi paylaşımı üzerine etkisi: İlaç sektörü çalışanlarına yönelik bir araştırma. Bilig 56, 99- 119.

Eryilmaz, İ., Dirik, D., \& Gülova, A. A. (2017). İş tatmininin belirleyicisi olarak lider-üye etkileşimi ve politik yetinin düzenleyici rolü. Uluslararası İktisadi ve İdari İncelemeler Dergisi, 16,167-182.

Fraenkel, J.R., Wallen, N.E., \& Hyun H.H. (2011). How to design and evaluate research in education. McGraw-Hill International Edition: New York.

Göksel, A., \& Ekmekçioğlu, E. (2017). Lider-üye etkileşiminin örgütsel özdeşleşme ile ilişkisinde işe bağl1lığın aracı rolü. Gazi Üniversitesi İktisadi ve İdari Bilimler Fakültesi Dergisi, 18(3), 721-747.

Griffin, R., \& Moorhead, G. (1986). Organizational Behavior. Houghton Mifflin Company.

Gürboyoğlu, J. (2009). Lider-üye etkileşiminin örgütsel adalet algısı ve tükenmişlik üzerine etkileri. Yüksek Lisans Tezi. Balıkesir Üniversitesi Sosyal Bilimler Enstitüsü, Balıkesir.

Karacan Doğan, P. (2018). Analysis of the relationship between organizational identification levels and organizational justice perceptions of academicians. Spormetre. 16(1), 107-118.

Kim, S., \& Andrew P.S. (2015). Relationships between organizational justice and coaches' attitudinal outcomes in intercollegiate sports. International Journal of Sports Science \& Coaching, 10(2), 305-326.

Köy, A. K. (2011). Yöneticiye güvenin iş tatmini üzerindeki etkisinde lider-üye etkileşiminin aracı rolü: istanbul ve kocaeli illerinde beyaz yakalılar üzerinde bir araştırma. Yüksek Lisans Tezi, Marmara Üniversitesi Sosyal 
Bilimler Enstitüsü, İstanbul.

Kuzucu, E. (2013). Örgütsel adalet algısının örgütsel vatandaşlık davranışına etkisinde lider-üye etkileşiminin aracılık rolü özel bir hastanede çalışan hemşireler üzerinde araştırma. Yüksek Lisans Tezi, Marmara Üniversitesi Sosyal Bilimler Enstitüsü, İstanbul.

Liden, R. C., \& Maslyn, J. M. (1998). Multidimensionality of Leader-member exchange: An empirical assessment through scale development. Journal of Management, 24(1), 43-72.

Masterson, S. S., Lewis, K., Goldman, B. M., \& Taylor, M. S. (2000). Integrating justice and social exchange: the differing effects of fair procedures and treatment of work relationships. Academy of Management Journal, 43(4): 738-748.

Mikula, G. (2002). Distribution of tasks: a view from the social psychology of justice. Steiner, D.D, Scarlicki D.P, Gilliland S.W. (Eds.) Emerging perspectives on managing organizational justice. Information Age Publications: Greenwich.

Moorman, R.H. (1991). The relationship between organizational justice and organizational citizenship behaviors: Do fairness perception influence employee citizenship? Journal of Applied Psychology, 76(6), 845-855.

Naktiyok, A., \& Yekeler K. (2006). Dönüştürücü liderliğin örgütsel bağlılık üzerine etkisinde etkileşimci liderlik davranışlarının rolü: Bir kamu kurumu örneği. Amme İdaresi Dergisi, 49(2), 105-143.

Özmen, Ö. N., Arbak, Y., \& Özer, P. S. (2007). Adalete verilen değerin adalet algıları üzerindeki etkisinin sorgulanmasına ilişkin bir araştırma. Ege Akademik Bakış Dergisi, 7(1), 17-33.

Öztürk, N., \& Şahin, S. (2017). Eğitim örgütlerinde örgüt kültürü ve öğretmen liderliği: lider-üye etkileşiminin aracılık rolü. Elementary Education Online, 16(4), 1451-1468.

Sayın, A., \& Şahin, M.Y. (2017). Adaptation of organizational justice in sports scale into the Turkish language: Validity and reliability study. Journal of Education and Training Studies, 5(2), 207-2014.

Süral Özer, P., \& Eker Urtekin, G. (2007). Örgütsel adalet algısı boyutları ve iş doyumu ilişkisi üzerine bir araştırma. Erciyes Üniversitesi İktisadi ve İdari Bilimler Fakültesi Dergisi, 28, 107-125.

Tabachnick, B. G., \& Fidell, L. S. (2007). Using multivariate statistics. Boston: Allyn and Bacon.

Taşkıran, E. (2011). Liderlik ve örgütsel sessizlik arasındaki etkileşim. Örgütsel adaletin rolü, Beta Basım Yayım: İstanbul.

Toğa, N. (2016). Örgütsel adalet algısının tükenmişlik sendromuna etkisi ve bir uygulama. Yüksek Lisans Tezi. İnönü Üniversitesi Sosyal Bilimler Enstitüsü, Malatya.

Tolukan, E., Şahin, M.Y., \& Koç, M. (2016). Cimnastik antrenörlerinin örgütsel özdeşleşme düzeyleri ve işten ayrılma niyeti ilişkisi. Turkish Studies, 11(8), 377-398.

Uysal, M. (2014). Genel liselerde görev yapan ögretmenlerin örgütsel adalet konusundaki algıları (Altındăg ilçesi örneği). Yüksel Lisans Tezi. Hacettepe Üniversitesi Eğitim Bilimleri Enstitüsü, Ankara.

Yürür, S., \& Nart, S. (2016). Örgütsel adalet algısı kamu çalışanlarının ihbar etme niyetinin belirleyicisi midir? Amme Idaresi Dergisi, 49(3), 117-148. 